\title{
Evaluation of Four Sunflower Hybrids (Helianthus annuus) under Three Irrigation Regimes and Two Doses of Fertilization on Flower Production
}

\author{
E. Carrillo-Ávila ${ }^{1}$, C. García-Acedo ${ }^{2}$, J. Arreola-Enríquez ${ }^{1}$, C. Landeros-Sánchez ${ }^{3}$, M. L. Osnaya-González ${ }^{1}$ \\ \& C. Castillo Aguilar ${ }^{1}$ \\ ${ }^{1}$ Colegio de Postgraduados Campus Campeche, Carretera Haltunchén-Edzná, Sihochac, Champotón, Campeche, \\ México \\ ${ }^{2}$ Secretaria de Desarrollo Rural, Calle Ricardo Castillo Oliver Lote 12, Barrio de San Francisco, Campeche, \\ México \\ ${ }^{3}$ Colegio de Postgraduados, Campus Veracruz, Carretera Federal Xalapa-Veracruz, vía Paso de Ovejas entre \\ Puente Jula y Paso San Juan, Tepetates, Veracruz, México \\ Correspondence: C. Landeros-Sánchez, Colegio de Postgraduados, Campus Veracruz, Km. 88.5 Carretera \\ Federal Xalapa-Veracruz, vía Paso de Ovejas entre Puente Jula y Paso San Juan, Tepetates, Veracruz, C.P. \\ 91690, México. Tel: 229-201-0770. E-mail: clandero@colpos.mx
}

Received: January 11, 2015 Accepted: February 25, 2015 Online Published: March 15, 2015

doi:10.5539/jas.v7n4p183 URL: http://dx.doi.org/10.5539/jas.v7n4p183

\begin{abstract}
Flower production is an income source for farming families. However, their productivity has been limited due to the lack of information on technical managements of crop species. In Mexico, 21,129 hectares are planted every year, with an annual production of 83,000 tons of flowers for decoration, and a total production value of 6,097 million Mexican pesos. In order to design agronomic management practices for sunflower production in the state of Campeche, three factors were evaluated: 1) sunflower hybrids, 2) time of irrigation and 3) fertilization doses, with four (hybrids: "Sunbright", "Prado Red Shade", "Full Sun" and "GH-382"), three (soil moisture tension at the start of irrigation of $-10,-35$ and $-60 \mathrm{kPa}$ ), and two (Fertilization formulas: 60-50-0, and 30-25-0) levels, respectively using a sub split plot arrangement nested in a complete random block design with three replicates. Response variables evaluated were: plant height (PH), stem diameter (SD), leaf width (LW), leaf length (LL), distance between nodes (DN), number of inflorescences (NF), inner diameter (IDF), external diameter (EDF) and capitulum weight $(\mathrm{CW})$. Irrigation affected PH, SD, LL, IDF, EDF, and CW. In all these variables, the highest values were found when irrigation was conducted at the lowest moisture tension $(-10 \mathrm{kPa})$. Likewise, in all those variables significant effect of hybrids were found, which confirms that the morphology of flowers is defined by genetic factors. Specifically, hybrid "Full Sun" had significantly higher PH, SD, and DN compared to the rest of the hybrids. "Full Sun" and "Sunbright" had the highest values for PH and LL. "Full Sun" and "GH 382" had significantly higher IDF and EDF. "Prado Red Shade" had significantly lower PH, SD, LL, CW and higher NF. Fertilization only had significant effects on LW, DN and CW. In conclusion, irrigation improves morphological characteristics of sunflower plants. If the farmer's objective is to produce larger flowers, then hybrids "Fun Sun" and "GH 382" are recommended. However, if the objective is to produce small flowers, hybrids "Sunbright" and "Prado Red Shade" are recommended. The latter is also suitable to produce a larger number of capitula.
\end{abstract}

Keywords: flower production, moisture tension, irrigation, morphological characteristics

\section{Introduction}

Floriculture represents a source of income for farming families. Thanks to traditional knowledge, families can produce a wide number of flower species, such as sunflower, madonna lily, heliconia, spikenard, tulips, etc. However, farmer's productivity is somehow limited due to the lack of information regarding the technical management of each species. In Mexico, there is a planted surface of 21,129 hectares, which are devoted to the production of flowers for decoration, with a total production of 83,000 tons of flowers, and a total production value of 6,097 million Mexican pesos. $80 \%$ of the total flower production is sold locally, $90 \%$ of the rest is 
exported to the United States (De la Madrid, 2009; Musalem et al., 2006). The most important producers by state are the State of Mexico with $60.80 \%$, Puebla with $15.24 \%$, Morelos with $8.27 \%$ and Mexico City with $7.89 \%$. These states make up a total national production of $92.99 \%$. As far as the production of sunflower, in 2012, 91,722 tons were harvested in Mexico, with an average yield of 626.9 tons of flower per hectare. The most important producers were located in the states of Morelos and the State of Mexico (SIAP, 2014).

It is important to note the difference between the production of sunflower for decoration and the production of sunflower used for forage or processed to produce oil for human consumption. When sunflower is used for forage or oil production, farmers want to produce plants with large capitula, with a higher seed production per plant. Furthermore, when sunflower us used as forage, farmers want to produce robust, taller and heavier plants. However, when sunflower used for decoration moderate size of capitula is preferred. In general, capitula with a diameter between 10 and $15 \mathrm{~cm}$ are preferred for flower arrangements. Sunflowers having a diameter between 7 and $8 \mathrm{~cm}$ are preferred for bouquets-type arrangements (Melgares, 2002).

The production of sunflower can be conducted not only under greenhouse conditions, but also outdoors. However, the latter system is limited to some region of Mexico, spring and summer time are the two seasons when this system can be established (Altman et al., 1977; Melgares, 2002). Among the sunflower hybrids produced in Mexico, some of the most important are Sun Rich Lemon, Sun Rich Orange, Sun Deep, Moonbright, Sunbirght, Sunbeam, Full Sun, Sun Goddes, Sunwheel, Type 61, Type 556, Type 555, Sun King, Schnittgold, Sungold, Golden Globe, Eversun, Golden Yellow, Eversun Bright Yellow, Evening Sun, Prado Red Shade and Sunseed (Melgares, 2002; Musalem et al., 2006).

In the state of Campeche, although flowers are commonly produced, this activity has not been able to reach a social and economic impact as observed with other activities such as horticulture and fruit production. This indicates that flowers production represents a potential opportunity because the state of Campeche has the soil and weather condition needed for the majority of tropical flowers, particularly sunflower. Furthermore, information describing the amounts and total values of products generated are lacking. In spite of that, the income generated due to flower marketing is 850,000 Mexican pesos annually (Mausalem et al., 2006). In the last five years, floriculture has been among the most important activities in the state of Campeche. Nonetheless, it is still considered as a relatively new activity for farmers, who commonly use family members to perform small scale agricultural activities. Many of these farmers having traditional knowledge can produce flowers from different species such as Madonna lylies, heliconia, spikenards, tulips, sunflower, etc. However, their productivity is limited due to the lack of information regarding the technical management of each species, which further decreases the productivity. Therefore, these small producers can only sell the flowers in local markets.

Because of that, further research on flower production is important in order to create ways for improving productivity. Increasing the size of land for flower production is also important to provide a wider range of products to the market.

The objective of the present study was to develop a set of management practices for sunflower production, which is expected to be beneficial to producers improving the quality of flower produced, and consequently increase their income. To do so, the response of four sunflower hybrids were evaluated (Sunbright, Prado Red Shade, Full Sun and GH-382) when applying differential irrigation regimes, under two doses of fertilization on flower production. We hypothesize that the evaluated hybrids have the quality and productive characteristics of the flower that will respond to the application of different levels of moisture soil tension at the start of irrigation and to different doses of fertilization.

\section{Materials and Methods}

\subsection{Experimental Location and Climate Conditions}

This study was conducted under field condition at the Center for Research, Production and Teaching "Xamantun " of the Technological Institute of Chiná, which is located on the Campeche-Tixmucuy road, km. 15. The geographic location are north latitude $19^{\circ} 43^{\prime} 20.9^{\prime \prime}$, west longitude $90^{\circ} 25^{\prime} 04^{\prime \prime}$ and being at $16 \mathrm{~m}$ above sea level. The predominant climate corresponds to $\mathrm{AW}_{0}$, according to the classification described by Köppen and modified by Garcia (1973), ambient characteristics are warm weather and sub humid with summer precipitations, distributed primarily from May to October, with an annual precipitation of 1,290 $\mathrm{mm}$. When averaged by month, maximum ambient temperature ranges from $28.5{ }^{\circ} \mathrm{C}$ (January) to $36.0{ }^{\circ} \mathrm{C}$ (May) and minimum ambient temperatures ranges from $15.8^{\circ} \mathrm{C}$ (January) to $22.5^{\circ} \mathrm{C}$ (May).

This study was conducted in a total Surface area of $500 \mathrm{~m}^{2}$ in a ferric Luvisol soil, also known as Kan-kab in the Mayan language. The infiltration of water in this type of soil is fast, and commonly has low levels of organic 
matter.

\subsection{Land Preparation}

Preparation of the land was conducted using heavy machinery two months before planting. The preparation consisted on weed elimination, land plowing, harrowing and land leveling.

\subsection{Installation of the Irrigation System}

After land preparation, a trickle irrigation system was installed by using PVC pipes having a diameter of 2", butterfly valves of 2 " diameter, and connectors having a caliber of 0.04 and T-Tape with a caliber of 8000 . The water output capacity was $5.281 \mathrm{~m}^{-1} \mathrm{~h}^{-1}$.

In order to control the irrigation, butterfly shut-off valves were installed. These valves allowed having a total control of the initiation and end of the irrigation in each experimental block.

\subsection{Planting}

Before planting, the land was irrigated continuously during $4 \mathrm{~h}$ in order to provide the appropriate conditions for seed germination. The distance between plants was $30 \mathrm{~cm}$ and the distance between furrows was $1 \mathrm{~m}$. Two seeds were deposited at each planting site. Planting was conducted in April, 2007.

\subsection{Experimental Design, Experimental Units and Treatments}

The following factors were evaluated: 1) moisture tension at the time of irrigation, 2) hybrids and 3) fertilization doses in a sub Split plot arrangement, nested in a complete random block design with three replicates. The factor moisture tension at the time of irrigation was located in the larger plots (blocks), hybrids were located in the medium size plots and the soil fertilization doses were located in the small size plots.

1) Experimental units: The larger plots (blocks), where the moisture tension levels were nested had dimensions of $10 \mathrm{~m}$ length $\times 5 \mathrm{~m}$ width (six furrows and $1 \mathrm{~m}$ spacing among them). The medium size plot, where hybrids were found had dimensions of $2.5 \mathrm{~m}$ width $\times 5 \mathrm{~m}$ length (three furrows widthwise) and the smaller size plots where the fertilization doses were found had dimensions of $2.5 \mathrm{~m}$ width $\times 2.5 \mathrm{~m}$ length.

2) Factor moisture tension at the time of irrigation: The effect of irrigation was evaluated based on different values of the moisture tension in the soil at the time of irrigation. By doing so, we took into account that the water output from the soil to the plant root is determined primarily by this variable. This procedure has been widely accepted in similar studies. For example, Lu et al. (2000), Salaya et al. (2002), Kang et al. (2004), Orozco and Pérez (2006), Wang et al. (2007a, 2007b), Rivera-Hernández et al. (2009, 2010), Sudhir-Yadav et al. (2011), Mahajan et al. (2012), and Carli et al. (2014).

Three levels of moisture tension were tested, levels were $-10,-35$ and $-60 \mathrm{kPa}$. The irrigation program applied to the larger plots was planned according to the moisture tension in the soil corresponding to each treatment, which was measured using the tensiometers of manometer installed at the center of each large plot, which had a porous capsule installed at $0.3 \mathrm{~m}$ deep immediately below the irrigation line.

The irrigation of each large plot was initiated when the reading of the manometer of the tensiometer reached the predetermined value and the irrigation continued until the manometer returned to cero (soil saturated with water). The irrigation time was recorded in each one of the larger plots within blocks. By doing so, the amount of water applied at each irrigation time for each treatment was calculated.

3) Factor hybrid: The levels (hybrids) were H1: "Sunbright". H2: "Prado Red Shade"; H3: "Full Sun", and H4: "GH-382".

4) Factor fertilization: The levels of fertilization of soil were F1: Fertilization formula 60-50-0; F2 and formula 30-25-0. These levels were defined based on results of the chemical composition analysis of the soil from the experimental plot. The physical and chemical analysis of the soil was conducted by taking samples $20 \mathrm{~cm}$ beneath the surface in each block, and then these samples were composited by block. The composited samples were shipped to the department of soil science of the National Institute of Forestry, Agriculture and Livestock Research (INIFAP, for its acronym in Spanish), in the state of Campeche for the analysis of chemical composition. The analytical methods and their interpretation were based on the Mexican Official Norm (NOM-021-RECNAT, 2000), and in the IFA (1992) standards. The physical and chemical analysis comprised: texture, $\mathrm{pH}$, electric conductivity, organic matter content, and $\mathrm{N}, \mathrm{P}, \mathrm{K}, \mathrm{Ca}$, and $\mathrm{Mg}$ contents. Based on the results, the amount of fertilizer applied to each plot was calculated adjusting the levels of nitrogen and phosphorous, taking into account that the soils of the region have very high $\mathrm{Ca}$ content, and, in calcareous soils, $\mathrm{P}$ interacts with Ca forming low solubility calcium phosphates, reducing its availability for crops (Hedley \& McLaughlin, 
2005; Wang et al., 2005; Mc Beath et al., 2006; Sánchez, 2007). Potassium was not added because the soil already had high concentrations of this nutrient.

The chemical ingredients used in the fertilizers were urea and triple lime super phosphate; the calculations were conducted according to Fernandez (2007). The amount of fertilizer to be used was divided in three parts to avoid nutrient loss by lixiviation, given the high water conductivity of the soil. The first fertilization was carried out at the time of planting, and the second was carried out 15 days later, with the third fertilization being applied 40 days after the planting date.

5) Treatments: Each of the treatments evaluated in this study resulted from the combination of the levels of each factor as listed in Table 1.

Table 1. Treatments evaluated

\begin{tabular}{|c|c|c|c|c|}
\hline Treatment & $\begin{array}{l}\text { Moisture tension at the } \\
\text { time of irrigation }(\mathrm{kPa})\end{array}$ & Hybrid & Fertilizer formula & Nomenclature \\
\hline 1 & -10 & Sunbright. & $60-50-00$ & I1 H1 F1 \\
\hline 2 & -10 & Sunbright. & $30-25-00$ & I1 H1 F2 \\
\hline 3 & -10 & Prado Red Shade. & $60-50-00$ & I1 H2 F1 \\
\hline 4 & -10 & Prado Red Shade. & $30-25-00$ & I1 H2 F2 \\
\hline 5 & -10 & Full Sun. & $60-50-00$ & I1 H3 F1 \\
\hline 6 & -10 & Full Sun. & $30-25-00$ & I1 H3 F2 \\
\hline 7 & -10 & GH 382. & $60-50-00$ & I1 H4 F1 \\
\hline 8 & -10 & GH 382. & $30-25-00$ & I1 H4 F2 \\
\hline 9 & -35 & Sunbright. & $60-50-00$ & I2 H1 F1 \\
\hline 10 & -35 & Sunbright. & $30-25-00$ & I2 H1 F2 \\
\hline 11 & -35 & Prado Red Shade. & $60-50-00$ & $\mathrm{I} 2 \mathrm{H} 2 \mathrm{~F} 1$ \\
\hline 12 & -35 & Prado Red Shade. & $30-25-00$ & $\mathrm{I} 2 \mathrm{H} 2 \mathrm{~F} 2$ \\
\hline 13 & -35 & Full Sun. & $60-50-00$ & I2 H3 F1 \\
\hline 14 & -35 & Full Sun. & $30-25-00$ & I2 H3 F2 \\
\hline 15 & -35 & GH 382. & $60-50-00$ & I2 H4 F1 \\
\hline 16 & -35 & GH 382. & $30-25-00$ & $\mathrm{I} 2 \mathrm{H} 4 \mathrm{~F} 2$ \\
\hline 17 & -60 & Sunbright. & $60-50-00$ & I3 H1 F1 \\
\hline 18 & -60 & Sunbright. & $30-25-00$ & I3 H1 F2 \\
\hline 19 & -60 & Prado Red Shade. & $60-50-00$ & I3 H2 F1 \\
\hline 20 & -60 & Prado Red Shade. & $30-25-00$ & I3 H2 F2 \\
\hline 21 & -60 & Full Sun. & $60-50-00$ & I3 H3 F1 \\
\hline 22 & -60 & Full Sun. & $30-25-00$ & I3 H3 F2 \\
\hline 23 & -60 & GH 382. & $60-50-00$ & I3 H4 F1 \\
\hline 24 & -60 & GH 382. & $30-25-00$ & I3 H4 F2 \\
\hline
\end{tabular}

Note. $\mathrm{H}=$ Hybrid; $\mathrm{I}=$ irrigation; $\mathrm{F}=$ Fertilizer.

\subsection{Variables Evaluated}

1) Vegetative development: In order to quantify the response variables to each of the factor levels, the following variables were evaluated during the vegetative development: Plant height $(\mathrm{PH})$, considered to be the distance between the base of the plant to the last pair of leaves; stem diameter (SD), measured using a vernier caliper at the base of the stem; width (LW) and length (LL) of the first pair of leaves measured from the tip of each leaf to 
the base of the petiole; distance between nodes (DN), considered as the length from the first two lower nodes.

2) Flowering: During this stage, variable evaluated were the following: total number of inflorescences (NF), inner diameters (IDF), and external diameter of the capitulum (EDF), these measurements were taken using a vernier caliper, and weight of the capitulum at the time of cutting $(\mathrm{CW})$.

3) Quantification of variables: Six plants were randomly collected from each experimental unit (small plot), which were used to determine the response variables.

\subsection{Harvest}

The harvest was conducted manually as the capitula from each of the hybrids reached the desired commercial size.

\subsection{Statistical Analysis of Data}

Data collected were subjected to analysis of variance as split plot arrangement nested in a complete randomized block design using SAS (2003). When differences were detected among variables from different treatments, the Tukey (1991) test was further conducted. Significance was declared at $\alpha=0.10$.

\section{Results and Discussion}

\subsection{Physical and Chemical Analysis of the Soil from Experimental Plot}

Results of the physical and chemical analysis of soil in the experimental terrain are presented in Table 2 . The type of soil is classified as clayey, with adequate content of organic matter, neutral $\mathrm{pH}$, and is a non-saline soil. The soil nitrogen and phosphorous contents were low, and can limit the sunflower growth; Instead, the potassium, calcium and magnesium content were high and very high for the latter two (IFA, 1992; Table 2) because of the calcareous substrate found. Because of that, the elevated concentrations of calcium resulted within the normal range found in the state of Campeche, which generally causes phosphorous deficiency because there is a fast fixation phosphorous in this type of soil, therefore immobilizing this nutrient (Sharpley, 2000; Hedley \& McLaughlin, 2005; Chintala et al., 2010, 2014). As a result of the soil chemical analysis, the following formulae were prepared: $60-50-0$ and 30-25-0 using only nitrate and phosphate fertilizers, which are the nutrients that the soil was lacking.

Table 2. Results of the physical and chemical analysis of the experimental plot

\begin{tabular}{lll}
\hline Determination & Value & Observations \\
\hline Sand (\%) & 22.61 & \\
Mud (\%) & 12.25 & Clay, according to the texture triangle of the USDA \\
Clay (\%) & 65.13 & \\
$\mathrm{pH}$ & 6.73 & Neutral \\
$\mathrm{EC}(\mathrm{dS} / \mathrm{m})$ & 0.30 & Non-saline soil \\
$\mathrm{OM}(\%)$ & 4.51 & High \\
Nitrates (meq/l) & 0.27 & Low \\
Phosphates (mg/l) & 2.28 & Low \\
Potasium (meq/l) & 12.24 & High \\
Calcium (meq/l) & 296.65 & Very high \\
Magnesium (meq/l) & 104.79 & Very high \\
\hline
\end{tabular}

Note. $\mathrm{EC}=$ Electrical conductivity of the extract of saturation; $\mathrm{MO}=$ Content of organic matter. Analytical methods and interpretation based on the Mexican Official Norm (NOM-021-RECNAT, 2000). Observations also based on IFA (1992) standards.

\subsection{Temporal Evolution of Moisture Tension}

Figure 1 illustrates the temporal evolution of the soil moisture tension, which increased as the radical systems absorbed the water from soil. The way irrigation times were defined in each large plot is also included. The arrows indicate the time of the initiation of the irrigation according to each treatment. Irrigations were more 
frequent for treatment R1 where the soil was maintained wetter, and irrigations was less frequent for treatment R3 where soil was maintained drier, though irrigations in the latter were of greater magnitude because the irrigation was stopped until the manometer of the tensiometer returned to cero. In other words, this happened when the soil was saturated with water. Once the irrigation was applied, the moisture tension decreased as a response to water supply.

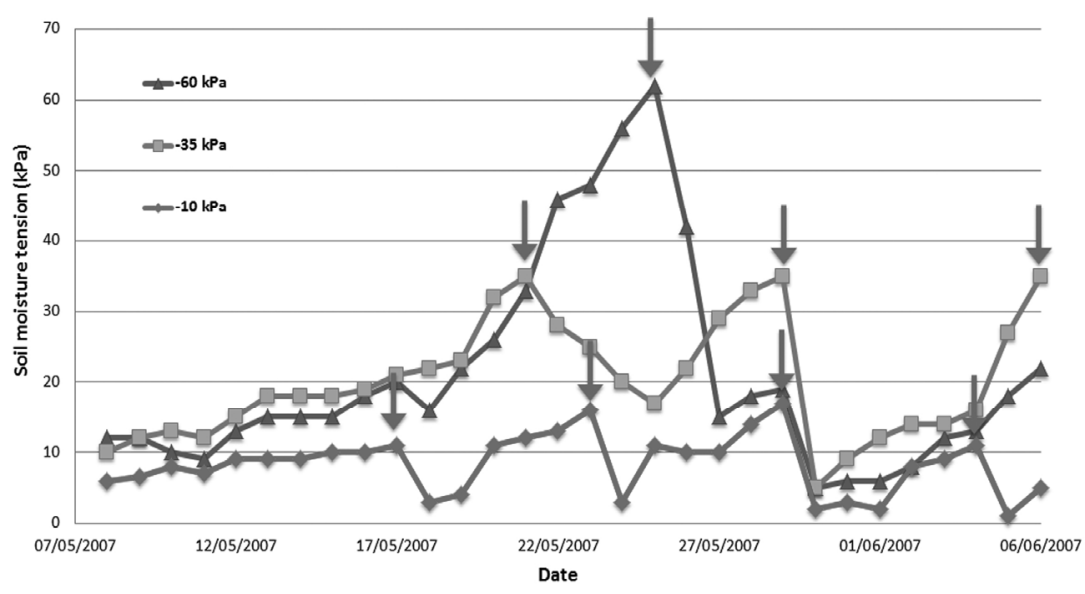

Figure 1. Evolution of the soil moisture tension

Note. Arrows indicate the time of the initiation of the irrigation for each treatment.

Table 3 lists the number of irrigations and the water sheet applied to each treatment at each moisture tension level in each block. It also includes the average water sheet and the total water sheet that each treatment received at each moisture tension level. In order to maintain a lower moisture tension in the soil, more irrigation is required, with the total amount needed being more than three times greater compared to the amount supplied to the drier treatment.

Table 3. Number of irrigations applied and water sheet applied to treatments at each moisture tension evaluated.

\begin{tabular}{|c|c|c|c|c|c|c|c|c|}
\hline \multirow{2}{*}{ Irrigation treatment } & \multicolumn{2}{|c|}{ Block one } & \multicolumn{2}{|c|}{ Block two } & \multicolumn{2}{|c|}{ Block three } & \multirow{2}{*}{ Aiw (mm) } & \multirow{2}{*}{ Aiw+pp (mm) } \\
\hline & IN & WL (mm) & IN & WL (mm) & IN & $\mathrm{WL}(\mathrm{mm})$ & & \\
\hline$-10 \mathrm{kPa}$ & 13 & 325 & 12 & 300 & 14 & 350 & 325 & 405.6 \\
\hline$-35 \mathrm{kPa}$ & 10 & 250 & 8 & 200 & 7 & 175 & 208.2 & 288.8 \\
\hline$-60 \mathrm{kPa}$ & 5 & 125 & 4 & 100 & 3 & 75 & 100 & 180.6 \\
\hline
\end{tabular}

Note. $\mathrm{IN}=$ irrigation number, $\mathrm{WL}=$ water sheet, Aiw $=$ Average irrigation water applied, Aiw $+\mathrm{pp}=\mathrm{Average}$ irrigation water plus precipitation.

\subsection{Analysis of Variance of Response Variables Evaluated}

\subsubsection{Factor Moisture Tension}

Table 4 lists the mean comparison found from the three irrigation treatments for variables studied. Irrigation applied in the wetter treatments (R1) yielded values significantly higher $(\mathrm{p} \leq 0.10)$ for variables $\mathrm{PH}, \mathrm{SD}, \mathrm{LL}$, IDF, EDF and $\mathrm{CW}$, and, even though no significant differences were found for the other variables, the greatest values were obtained when irrigation was applied at the lowest moisture tension $(-10 \mathrm{kPa})$, except for variable NF. These results suggest that when the water stress is increased, blooming is stimulated, and a greater number of inflorescences are produced. Similar responses have been observed in other cultivated species (Southwick \& Davenport, 1986; Cuevas et al., 2009; Uçan \& Killi, 2010; Cuevas et al., 2012). It is important to note, however, that this also resulted in smaller size inflorescences (Table 4). Nonetheless, this effect was only observed in the hybrids "Prado Red Shape" and "GH 382", which are characterized for producing several inflorescences. The other hybrids only produce one flower per plant. 
Table 4. Comparison of variables evaluated for irrigation treatments

\begin{tabular}{|c|c|c|c|c|}
\hline \multirow{2}{*}{ Variable } & \multicolumn{3}{|c|}{ Irrigation treatment } & \multirow{2}{*}{ MSD } \\
\hline & $-10 \mathrm{kPa}$ & $-35 \mathrm{kPa}$ & $-60 \mathrm{kPa}$ & \\
\hline $\mathrm{PH}(\mathrm{cm})$ & $145.3 \mathrm{a}$ & $127.0 \mathrm{ab}$ & $115.0 \mathrm{~b}$ & 29.8 \\
\hline $\mathrm{SD}(\mathrm{mm})$ & $23.0 \mathrm{a}$ & $18.1 \mathrm{~b}$ & $17.5 \mathrm{~b}$ & 4.0 \\
\hline $\mathrm{LW}(\mathrm{cm})$ & $13.4 \mathrm{a}$ & $11.0 \mathrm{a}$ & $11.2 \mathrm{a}$ & 3.4 \\
\hline $\mathrm{LL}(\mathrm{cm})$ & $44.1 \mathrm{a}$ & $38.3 \mathrm{~b}$ & $37.7 \mathrm{~b}$ & 5.0 \\
\hline $\mathrm{DN}(\mathrm{cm})$ & $10.6 \mathrm{a}$ & $8.9 \mathrm{a}$ & $8.8 \mathrm{a}$ & 5.3 \\
\hline NF & $6.7 \mathrm{a}$ & $6.4 \mathrm{a}$ & $7.2 \mathrm{a}$ & 2.4 \\
\hline IDF (mm) & $68.4 \mathrm{a}$ & $61.5 \mathrm{ab}$ & $50.5 \mathrm{~b}$ & 17.9 \\
\hline $\mathrm{EDF}(\mathrm{mm})$ & $76.2 \mathrm{a}$ & $66.7 \mathrm{ab}$ & $55.8 \mathrm{~b}$ & 20.1 \\
\hline $\mathrm{CW}(\mathrm{g})$ & $160.3 \mathrm{a}$ & $147.9 \mathrm{a}$ & $115.9 \mathrm{~b}$ & 42.8 \\
\hline
\end{tabular}

Note. $\mathrm{PH}=$ Plant height; $\mathrm{SD}=$ Stem diameter; $\mathrm{LW}=$ Leaf width; $\mathrm{LL}=$ Leaf length; $\mathrm{DN}=$ Distance between nodes; $\mathrm{NF}=$ Total number of inflorescences; IDF $=$ Inner diameter of the flower; $\mathrm{EDF}=$ External diameter of the flower; $\mathrm{CW}=$ Weight of the flower; MSD $=$ Minimum significant difference. Within rows, means with the same letter are no statistically different (Tukey, $\mathrm{p} \leq 0.10$ ).

The positive effect of irrigation when applied at low (near cero) moisture tension has been widely reported in a range of plant species (Chintala et al., 2012a, 2012b). For example, Kang et al. (2004) and Wang et al. (2007b) obtained better yields for potato when irrigation was applied at $-25 \mathrm{kPa}$; Orozco and Perez (2006) obtained higher yields for banana when irrigation was applied at $-10 \mathrm{kPa}$. However, the best profit to cost ratio was obtained when irrigation was applied at $-25 \mathrm{kPa}$. Rivera-Hernandez et al. $(2009,2010)$ tested different values of moisture tension at the time of irrigation on the growth and quality of corn, and they found that treatments that were wetter $(-5$ and $-30 \mathrm{kPa})$ had the best results from growth and quality. Sudhir-Yadav et al. (2011) tested different irrigation treatments for rice, defined based on the moisture tension in the soil at $20 \mathrm{~cm}$ deep: when irrigation was applied at $-20 \mathrm{kPa}$ maximum values for crop and maximum water productivity were obtained.

For the production of sunflower, the effects of irrigation has been tested, response variables that have been tested are seed yield and the quality of the oil; significant effects of irrigation have been found for both variables (Flagella et al., 2002; Sezen et al., 2011a, 2011b; Jalilian et al., 2012). However, none of these studies has utilized soil moisture tension as an indicator of the time when irrigation is needed. As for the production of sunflower for decoration, there is limited published information regarding the evaluation of irrigation. Friedman et al. (2007) tested the effect of irrigation with drinkable water and with treated waste water on the quality of the flower, but they did not evaluate different levels of moisture of the soil.

\subsubsection{Factor Hybrid}

The hybrid "Full Sun" was, in general, of larger size not only for variables characteristics of the vegetative development, but also for those defining the distinctive traits of the inflorescences: it was significantly taller, with thicker stems and longer distance between nodes compared to the rest of the hybrids (Table 5). As far as the size of the flower, the hybrid "Full Sun" and "GH-382" had similar inner and external diameters of the flowers. Hybrid "Full Sun" had significantly lower number of flowers compared to "GH-382" and "Prado Red Shade", respectively.

On the other hand, the latter hybrid consistently had lower values for almost all the evaluated variables, being of lower height, with mid-size inflorescences having a size statistically similar to those found for "Sunbright". However, unlike the rest of the hybrids, "Sunbright" produced in average almost 22 inflorescences per plant, which contrasts the production of the others: "GH-382" barely produced a liter over 3 inflorescences. "Sunbright" and "Full Sun" only have one inflorescence per plant. 
Table 5. Comparison mean of evaluated variables for the hybrids

\begin{tabular}{llllll}
\hline Variable & \multicolumn{5}{c}{ Hybrids } \\
\cline { 2 - 5 } & GH 382 & Sunbright & Full Sun & Prado Red Shade \\
\hline PH $(\mathrm{cm})$ & $117.3 \mathrm{~b}$ & $112.3 \mathrm{~b}$ & $192.8 \mathrm{a}$ & $94.1 \mathrm{c}$ & 14.1 \\
SD $(\mathrm{mm})$ & $19.3 \mathrm{~b}$ & $18.8 \mathrm{~b}$ & $25.0 \mathrm{a}$ & $15.1 \mathrm{c}$ & 2.5 \\
LW $(\mathrm{cm})$ & $11.3 \mathrm{~b}$ & $13.0 \mathrm{a}$ & $13.1 \mathrm{a}$ & $10.2 \mathrm{~b}$ & 1.6 \\
LL $(\mathrm{cm})$ & $38.4 \mathrm{bc}$ & $43.6 \mathrm{a}$ & $42.5 \mathrm{ab}$ & $35.7 \mathrm{c}$ & 4.7 \\
DN $(\mathrm{cm})$ & $8.8 \mathrm{~b}$ & $8.8 \mathrm{~b}$ & $12.1 \mathrm{a}$ & $8.1 \mathrm{~b}$ & 2.6 \\
NF & $3.2 \mathrm{~b}$ & $1.0 \mathrm{~b}$ & $1.0 \mathrm{~b}$ & $21.7 \mathrm{a}$ & 2.8 \\
IDF $(\mathrm{mm})$ & $68.7 \mathrm{a}$ & $50.7 \mathrm{~b}$ & $76.6 \mathrm{a}$ & $44.7 \mathrm{~b}$ & 11.2 \\
EDF $(\mathrm{mm})$ & $76.4 \mathrm{a}$ & $54.0 \mathrm{~b}$ & $84.0 \mathrm{a}$ & $50.5 \mathrm{~b}$ & 12.5 \\
CW $(\mathrm{g})$ & $253.4 \mathrm{a}$ & $129.7 \mathrm{~b}$ & $119.7 \mathrm{~b}$ & $62.6 \mathrm{c}$ & 56.8 \\
\hline
\end{tabular}

Note. $\mathrm{PH}=$ Plant height; $\mathrm{SD}=$ Stem diameter; $\mathrm{LW}=$ Leaf width; $\mathrm{LL}=$ Leaf length; $\mathrm{DN}=$ Distance between nodes; $\mathrm{NF}=$ Total number of inflorescences; IDF $=$ Inner diameter of the flower; $\mathrm{EDF}=$ External diameter of the flower; $\mathrm{CW}=$ Weight of the flower; MSD $=$ Minimum significant difference. Within rows, means with the same letter are no statistically different (Tukey, $\mathrm{p} \leq 0.10$ ).

Furthermore, hybrid "GH 382" produced capitula that were significantly heavier compared to the capitula of the other hybrids: in average their capitula weighed more than $250 \mathrm{~g}$, maybe because this hybrid is primarily used for seed and for oil production (Diaz-Zorrita et al., 2003), whereas the capitula for hybrid "Prado Red Shape" barely exceeded $60 \mathrm{~g}$. In spite of the fact that the hybrid "Full Sun" produced larger capitula, its average weight was $119 \mathrm{~g}$, a value much lower than hybrid "GH 382". These latter two hybrids were the largest. It is important to note that morphological differences found are a consequence of genetic factors.

\subsubsection{Factor Fertilization}

In spite of the low level of the soil fertility, mainly in the macronutrients nitrogen and phosphorous (Table 2), the supply of the fertilization doses evaluated in this study did not have significant statistical differences in most of the variables. In addition, there were no edaphological problems observed in the plants due to nutrient deficiency. Fertilization level only had significant effects on the variables width of the first leaves, distance between nodes and weight of the inflorescences. Although, surprisingly, in the latter variable, the averaged maximum values were obtained when the lower fertilization level was applied (Table 6). For the rest of the variables, the higher values were obtained when the higher level of fertilizer was applied. Similar reports regarding the fertilization of sunflower have been conducted to evaluate the yield and quality of the seed (Ogunremi, 1986; Figueiredo \& Grassi, 2007; Amanullah \& Khan, 2011). However, there is limited information evaluating the fertilization of the crop on the quality of the flower. For example, Ahmad et al. (2012) evaluated five levels of nitrogen on the development and nutritional state of two hybrids of sunflower; they found that fertilization with nitrogen stimulated the growth of the stem; it also stimulated the concentration of nitrogen in the tissues. However, level of nitrogen did not affect the days needed for cutting the inflorescences. Pereira et al. (2009) evaluated the fertilization of the hybrid "Sunbright" with potassium silicate, similar to our findings; they did not find clear differences in the morphological characteristics of the flower as a response to the treatments. 
Table 6. Comparison of the mean of variables evaluated for the fertilization treatments

\begin{tabular}{llll}
\hline \multirow{2}{*}{ Variable } & \multicolumn{2}{c}{ Fertilization treatments } & MSD \\
\cline { 2 - 3 } & $\mathbf{3 0 - 2 5 - 0 0}$ & $\mathbf{6 0 - 5 0 - 0 0}$ & \\
\hline PH $(\mathrm{cm})$ & $127.9 \mathrm{a}$ & $130.4 \mathrm{a}$ & 2.8 \\
SD $(\mathrm{mm})$ & $19.3 \mathrm{a}$ & $19.8 \mathrm{a}$ & 0.6 \\
LW $(\mathrm{cm})$ & $11.5 \mathrm{~b}$ & $12.2 \mathrm{a}$ & 0.3 \\
LL $(\mathrm{cm})$ & $39.7 \mathrm{a}$ & $40.4 \mathrm{a}$ & 0.9 \\
DN $(\mathrm{cm})$ & $9.0 \mathrm{~b}$ & $9.8 \mathrm{a}$ & 0.5 \\
NF & $6.6 \mathrm{a}$ & $6.9 \mathrm{a}$ & 0.5 \\
IDF $(\mathrm{mm})$ & $59.5 \mathrm{a}$ & $60.7 \mathrm{a}$ & 2.1 \\
EDF $(\mathrm{mm})$ & $65.3 \mathrm{a}$ & $67.1 \mathrm{a}$ & 2.2 \\
CW $(\mathrm{g})$ & $150.5 \mathrm{a}$ & $132.2 \mathrm{~b}$ & 5.6
\end{tabular}

Note. $\mathrm{PH}=$ Plant height; $\mathrm{SD}=$ Stem diameter; $\mathrm{LW}=$ Leaf width; $\mathrm{LL}=$ Leaf length; $\mathrm{DN}=$ Distance between nodes; $\mathrm{NF}=$ Total number of inflorescences; IDF $=$ Inner diameter of the flower; $\mathrm{EDF}=$ External diameter of the flower; $\mathrm{CW}=$ Weight of the flower; MSD $=$ Minimum significant difference. Within rows, means with the same letter are no statistically different (Tukey, $\mathrm{p} \leq 0.10$ ).

\subsubsection{Effects of the Double and Triple Interactions}

We only found significant effects in the double interaction hybrid $\times$ fertilization for the variable weight of the capitulum. For the rest of the double interactions of the other variables, no statistical significant effects were found. These findings indicate that practically none of the factors interacted with each other. However, significant effects were found for the triple interaction for the variable number of total inflorescences per plant. Furthermore, highly significant effects were found for the triple interaction for the rest of the variables. These interactions, both double and triple, were primarily a consequence of morphological differences attributed to genetic factors among hybrids. These data are presented in section 3.3.2, which were considered as a factor in the experimental design.

\section{Conclusions}

Irrigation significantly affected not only growth variables, but also the morphological characteristics of the inflorescences of sunflower. We found that when irrigation is applied when the soil moisture tension is $-10 \mathrm{kPa}$, maximum values variables for vegetative growth and quality of the inflorescences were obtained. More specifically, plants were significantly taller, with thicker stems, larger leaves, and larger inner and external inflorescence diameters. In addition, the weight of the flowers were significantly greater compared to treatments where lower levels of water were applied.

We found clearly no significant effects of the factor irrigation and fertilization on the variable number of capitula. This finding indicates that that variable depend on genetic factors rather than on the stress that the plants were experiencing.

Significant effects were found in all variables among hybrids for variables attributed to morphological differences due to genetic factors. More specifically "Full Sun" was taller with a larger diameter of the stem, whereas "Prado Red Shade" was significantly smaller. The latter had significantly higher number of capitula. The capitula of hybrids "Full Sun" and "GH 382" had diameters significantly greater and the capitula of "GH 382 " were significantly heavier.

We only found significant effects of fertilization factor on the variable weight of the capitula. Double interactions for the hybrid $\times$ fertilization were not statistically significant, except for the variable $\mathrm{CW}$.

Triple interactions of all evaluated variables were significant. Double interactions and triple interaction were observed as a consequence of morphological differences existing among hybrids, which are attributed to genetic factors. 


\section{Acknowledgements}

To Colegio de Postgraduados, Campus Campeche and Campus Veracruz (LPI-8 Impacto y Mitigación del Cambio Climático) for financial support. Thanks also to Ing. Juan Manuel Hernández Pérez for assistance in the preparation of tables and figures.

\section{References}

Ahmad, I., Doleb, J. M., \& Nelson, P. (2012). Nitrogen application rate, leaf position and age affect leaf nutrient status of five specialty cut flowers. Scientia Horticulturae, 142(13), 14-22. http://dx.doi.org/10.1016/j.scienta.2012.04.009.

Amanullah, \& Khan, M. W. (2011). Interactive Effect of Potassium and Phosphorus on Grain Quality and Profitability of Sunflower in Northwest Pakistan. Pedosphere, 21(4), 532-538. http://dx.doi.org/10.1016/S1002-0160(11)60155-0.

Carli, C., Yuldasheva, F., Khalikova, D., Condorib, B., Maresc, V., \& Monneveuxc, P. (2014). Effect of different irrigation regimes on yield, water use efficiency and quality of potato (Solanum tuberosum L.) in the lowlands of Tashkent, Uzbekistan: A field and modeling perspective. Field Crops Research, 163, 90-99. http://dx.doi.org/10.1016/j.fcr.2014.03.021

Chintala, R., McDonald, L. M., \& Bryan, W. B. (2010). Grouping soils by taxonomy order to improve lime recommendations. Communications in Soil Science and Plant Analysis, 41, 1594-1603. http://dx.doi.org/10.1080/00103624.2010.485239

Chintala, R., Schumacher, T. E., McDonald, L. M., Clay, D. E., Malo, D. D., Clay, S. A., ... Julson, J. L. (2014). Phosphorus sorption and availability in biochars and soil biochar mixtures. CLEAN-Soil Air Water, 42(5), 626-634. http://dx.doi.org/10.1002/clen.201300089

Chintala, R., McDonald, L. M., \& Bryan, W. B. (2012a). Effect of soil water and nutrients on productivity of Kentucky bluegrass systems in acidic soils. Journal of Plant Nutrition, 35, 288-303. http://dx.doi.org/10.1080/01904167.2012.636131

Chintala, R., McDonald, L. M., \& Bryan, W. B. (2012b). Optimization of water potential and nutrient levels for Kentucky bluegrass-white clover mixture on acidic soils. Biotechnology, Agronomy, Society and Environment, 16, 167-177.

Cuevas, J., Pinillos, V., Cañete, M. L., González, M., Alonso, F., Fernández, M. D., \& Hueso, J. J. (2009). Optimal levels of postharvest deficit irrigation for promoting early flowering and harvest dates in loquat (Eriobotrya japonica Lindl.). Agricultural Water Management, 96, 831-838. http://dx.doi.org/10.1016/j.agwat.2008.11.002

Cuevas, J., Pinillos, V., Cañete, M. L., Parra, S., González, M., Alonso, F., ... Hueso, J. J. (2012). Optimal duration of irrigation withholding to promote early bloom and harvest in 'Algerie' loquat (Eriobotrya $\begin{array}{lllll}\text { japonica Lindl.). } & \text { Agricultural }\end{array}$ http://dx.doi.org/10.1016/j.agwat.2012.05.006

De la Madrid, E. (2009). La floricultura en México. Revista El Mexicano. Retrieved from http://www.oem.com.mx

Díaz-Zorita, M., Duarte, G. A., \& Plante, D. Z. (2003). El cultivo del girasol. Asociación Argentina de Girasol ASAGIR. Retrieved from http://www.asagir.org.ar/Publicaciones/Cuadernillo_web.pdf

Fernández, R. (2007). El Cultivo de Flores en Venezuela. Boletín Informativo.

Figueiredo, L. T., \& Grassi, F. H. (2007). Level of sewage sludge for the productivity of sun flower. J. Soil Sc. Plant Nutr., 7(3), 16-25. http://dx.doi.org/10.4067/S0718-27912009000300007

Flagella, Z., Rotunno, T., Tarantino, E., Di Caterina, R., \& De Caro, A. (2002). Changes in seed yield and oil fatty acid composition of high oleic sunflower (Helianthus annuus L.) hybrids in relation to the sowing date and the water regime. European Journal of Agronomy, 17(3), 221-230. http://dx.doi.org/10.1016/S1161-0301(02)00012-6

Friedman, H., Bernstein, N., Bruner, M., Rot, I., Ben-Noon, Z., Zuriel, A., ... Hagiladi, A. (2007). Application of secondary-treated effluents for cultivation of sunflower (Helianthus annuus L.) and celosia (Celosia argentea L.) as cut flowers. Scientia Horticulturae, 115, 62-69. http://dx.doi.org/10.1016/j.scienta.2007.07.003 
García, E. (1973). Modificaciones al sistema de clasificación climática de Köppen (para adaptarlo a las condiciones de la República Mexicana). Segunda edición corregida y aumentada. Instituto de Geografía. Universidad Nacional Autónoma de México. México.

Hedley, M. J., \& McLaughlin, M. J. (2005). Reactions of phosphate fertilizers and byproducts in soils. In J. T. Sims \& A. N. Sharpley (Eds.), Phosphorus: Agricultura and the environment (Agron. Monogr., pp. 181-252, No. 46). ASA, CSSA, and SSSA, Madison, WI. http://dx.doi.org/10.2134/agronmonogr46.c7

IFA (International Fertilizer Association). (1992). World fertilizer use manual (p. 427). Germany.

Jalilian, J., Modarres-Sanavy, S. A. M., Saberali, S. F., \& Sadat-Asilan, K. (2012). Effects of the combination of beneficial microbes and nitrogen on sunflower seed yields and seed quality traits under different irrigation regimes. Field Crops Research, 127, 26-34. http://dx.doi.org/10.1016/j.fcr.2011.11.001

Kang, Y., Wang, F. X., Liu, H. J., \& Yuan, B. Z. (2004). Potato evapotranspiration and yield under different drip irrigation regimes. Irrig. Sci., 23, 133-143. http://dx.doi.org/10.1007/s00271-004-0101-2

Lu, J., Ookawa, T., \& Hirasawa, T. (2000). The effects of irrigation regimes on the water use, dry matter production and physiological responses of paddy rice. Plant and Soil, 223, $207-216$. http://dx.doi.org/10.1023/A:1004898504550

Mahajan, G., Chauhan, B. S., Timsina, J., Singh, P. P., \& Kuldeep, S. (2012). Crop performance and water- and nitrogen-use efficiencies in dry-seeded rice in response to irrigation and fertilizer amounts in northwest India. Field Crops Research, 134, 59-70. http://dx.doi.org/10.1016/j.fcr.2012.04.011

Mc Beath, T. M., Smernik, R. J., Lombi, E., \& McLaughlin, M. J. (2006). Hydrolysis of pyrophosphate in a highly calcareous soil: a solid-state phosphorus-31 NMR study. Soil Sci. Soc. Am. J., 70, 856-862. http://dx.doi.org/10.2136/sssaj2005.0184

Melgares de, A., J. (2002). El cultivo del girasol para flor cortada. Revista Flormarket Ed. Verdimedia, España, aи̃o $\operatorname{II}(2)$, 55-61.

Musalem, L. O., Olvera, G. J., Ochoa, B. R., \& Ortega, R. C. (2006). La floricultura Mexicana, el gigante que está despertando. Revista Claridades Agropecuarias, 154, 3-38. Retrieved from http://www.infoaserca.gob.mx/claridades/revistas/154/ca154.pdf

NOM-021-RECNAT. (2000). Especificaciones de fertilidad, salinidad y clasificación de suelos. Estudios, muestreo y análisis (p. 88). SEMARNAT, México.

Ogunremi, E. A. (1986). Effects of nitrogen fertilization and harvest time on sunflower yield and hollow seededness. Field Crops Research, 13, 44-53. http://dx.doi.org/10.1016/0378-4290(86)90006-7

Orozco, R. J., \& Pérez, Z. O. (2006). Tensión de humedad del suelo y fertilización nitrogenada en plátano (Musa AAA Simmonds) cv. Gran Enano. Agrociencia, 40, 149-162.

Pereira, C. M., Zanão, J. L. A., Saraiva, G. J. A., \& Barbosa, J. G. (2009). Silicon improves ornamental pot sunflower production and quality. Ciência Rural, Santa Maria, 39(8), 2394-2399. http://dx.doi.org/10.1590/S0103-84782009005000194

Rivera-Hernández, B., Carrillo-Ávila, E., Obrador-Olán, J. J., Juárez-López, J. F., Aceves-Navarro, L. A., \& García-López, E. (2009). Soil moisture tension and phosphate fertilization on yield components of A-7573 sweet corn (Zea mays L.) hybrid, in Campeche, Mexico. Agricultural Water Management, 96, 1285-1292. http://dx.doi.org/10.1016/j.agwat.2009.03.020

Rivera-Hernández, B., Carrillo-Ávila, E., Obrador-Olán, J. J., Juárez-López, J. F., \& Aceves-Navarro, L. A. (2010). Morphological quality of sweet corn (Zea mays L.) ears as response to soil moisture tension and phosphate fertilization in Campeche, Mexico. Agricultural Water Management, 97(9), 1365-1374. http://dx.doi.org/10.1016/j.agwat.2010.04.001

Salaya-Domínguez, J. M., Carrillo-Ávila, E., Palacios-Vélez, O. L., Aceves-Navarro, L. A., \& Juárez-López, J. F. (2002). Respuesta del cultivo de sandía (Citrullus vulgaris Schrad) al potencial del agua en el suelo. Revista Fitotecnia Mexicana, 25(2), 127-133.

Sánchez, C. A. (2007). Phosphorus. In A. V. Broker \& D. J. Pilbeam, (Eds.), Handbook of Plant Nutrition (pp. 51-82). Grup. Boca Raton. London, New York: Taylor Francis.

SAS (Statistical Analysis System). (2003). Statistical Analysis System for Windows 9.1.3. Service Pack 2. SAS Institute Inc., Cary, NC, USA. 
Sezen, S. M., Yazar, A., Kapur, B., \& Tekinb, S. (2011a). Comparison of drip and sprinkler irrigation strategies on sunflower seed and oil yield and quality under Mediterranean climatic conditions. Agricultural Water Management, 98, 1153-1161. http://dx.doi.org/10.1016/j.agwat.2011.02.005

Sezen, S. M., Yazar, A., \& Tekinb, S. (2011b). Effects of partial root zone drying and deficit irrigation on yield and oil quality of sunflower in a Mediterranean environment. Irrigation and Drainage, 60(4), 499-508. http://dx.doi.org/10.1002/ird.607

Sharpley, A. (2000). Phosphorus availability. In M. E. Sumner (Ed.), Handbook of Soil Science (pp. D18-D37). CRC Press, New York.

SIAP. (2014). Servicio de Información Agroalimentaria y Pesquera (SIAP). Secretaría de Agricultura, Ganadería, Desarrollo Rural Pesca y Alimentación (SAGARPA), México. Retrieved from http://www.siap.gob.mx

Southwick, S. M., \& Davenport, T. L. (1986). Characterization of water stress and low temperature effects on flower induction in citrus. Plant Physiol., 81, 26-29. http://dx.doi.org/10.1104/pp.81.1.26

Sudhir-Yadav, E., Humphreys, S. S., Kukal, G. G., \& Rangarajan, R. (2011). Effect of water management on dry seeded and puddled transplanted rice Part 2: Water balance and water productivity. Field Crops Research, 120, 123-132. http://dx.doi.org/10.1016/j.fcr.2010.09.003

Tukey, J. W. (1991). The philosophy of multiple comparisons. Statistical Science, 6, 100-116. http://dx.doi.org/10.1214/ss/1177011945

Uçan, K., \& Killi, F. (2010). Effects of different irrigation programs on flower and capsule numbers and shedding percentage of sesame. Agricultural Water Management, 98, 227-233. http://dx.doi.org/10.1016/j.agwat.2010.08.005

Wang, Q. R., Li, J., Li, Z., \& Christie, P. (2005). Screening Chinese wheat germoplasm for phosphorus efficiency in calcareous soils. J. Plant Nutr., 28, 489-505. http://dx.doi.org/10.1081/PLN-200049186

Wang, D., Kang, Y., \& Wan, S. (2007a). Effect of soil matric potential on tomato yield and water use under drip irrigation condition. Agricultural Water Management, 87, 180-186. http://dx.doi.org/10.1016/j.agwat.2006.06.021

Wang, F. X., Kang, Y., Liu, S. P., \& Hou, X. Y. (2007b). Effects of soil matric potential on potato growth under drip irrigation in the North China Plain. Agricultural Water Management, 88, 34-42. http://dx.doi.org/10.1016/j.agwat.2006.08.006

\section{Copyrights}

Copyright for this article is retained by the author(s), with first publication rights granted to the journal.

This is an open-access article distributed under the terms and conditions of the Creative Commons Attribution license (http://creativecommons.org/licenses/by/3.0/). 